\title{
LITERASI INFORMASI DALAM KERANGKA PENGEMBANGAN PENDIDIKAN MASYARAKAT
}

\author{
Dinno Mulyono', Ansori \\ 1,2 IKIP Siliwangi, Cimahi, Indonesia \\ ${ }^{1}$ dinno@ikipsiliwangi.ac.id, ${ }^{2}$ ansoryalb@ikipsiliwangi.ac.id \\ Received: Oktober 2019 ; Accepted: Desember 2019
}

\begin{abstract}
Utilization of technology and information in the community requires a comprehensive framework, related to education and its implementation in the midst of community education unit institutions, especially relating to various approaches in the process of managing information to improve the quality of people's lives, not only related to the development of reading, writing and writing competencies counting, but dealing with the management of information itself in order to provide meaning and benefits for the quality of people's lives. With the community education approach, a learning model can be developed by utilizing the accessibility and quality of information technology to support existing empowerment programs. Including empowering community education units to provide support for the use of information in increasing the capacity of the community itself.
\end{abstract}

Keywords: information literacy, public education

\begin{abstract}
Abstrak
Pemanfaatan teknologi dan informasi di tengah masyarakat membutuhkan sebuah kerangka yang menyeluruh, terkait dengan pendidikan dan implementasinya di tengah kelembagaan satuan pendidikan masyarakat, terutama berhubungan dengan berbagai pendekatan dalam proses pengelolaan informasi untuk peningkatan kualitas kehidupan masyarakat, tidak hanya berkaitan dengan pengembangan kompetensi membaca, menulis dan berhitung, tapi berhubungan dengan manajemen informasi itu sendiri agar dapat memberikan makna dan manfaat bagi kualitas kehidupan masyarakat. Dengan pendekatan pendidikan masyarakat, maka dapat dikembangkan sebuah model pembelajaran dengan memanfaatkan aksesibilitas dan kualitas teknologi informasi untuk menunjang program pemberdayaan yang ada. Termasuk memberdayakan satuan pendidikan masyarakat untuk memberikan dukungan atas pemanfaatan informasi dalam peningkatan kapasitas masyarakat itu sendiri.
\end{abstract}

Kata Kunci: literasi informasi, pendidikan masyarakat

How to Cite: Ansori,A \& Mulyono, D. (2020). Literasi Informasi dalam Kerangka Pendidikan Masyarakat. Comm-Edu (Community Education Journal), 3(1), 1-5.

\section{PENDAHULUAN}

Penguasaan informasi menjadi salah satu penguatan utama dalam membangun dan mengembangkan kapasitas masyarakat. Hal ini karena denan adanya pengembangan berbagai potensi masyarakat membutuhkan kerangka kerja dan koridor program yang jelas yang hanya bisa dibangun dengan mengembangkan berbagai kapasitas pendidikan yang mengedepankan aksesibilitas terhadap informasi, baik dalam hal identifikasi kebutuhan, perencanaan, pelaksanaan, Literasi informasi merupakan salah satu program utama dalam membangun dan mengembangkan berbagai konsep yang berasal dari berbagai informasi yang berkaitan dengan proses pencarian, pengelolaan dan pemanfaatan informasi. Dalam kondisi tertentu, bentuk illitearcy (kebutahurufan) membentuk adanya pemahaman yang tidak sempurna dalam mengelola aksesibilitas informasi yang semakin masif. Terutama karena saat ini setiap orang 
dapat menajdi jurnalis dan komentator amatiran (Palupi, 2019). Bilamana aksesibilitas informasi tidak diimbangi dengan kesadaran literasi informasi, maka memungkinkan semakin banyaknya berita bohong (hoax) dan berita penebar kebencian (hate speech) yang dapat menimbulkan keresahan di tengah masyarakat (Palupi, 2019). Berdasarkan data informasi dari Kepala Subdit IT dan Cyber Crime Direktorat Tindah Pidana Ekonomi Khusus Bareskrim Polri, Kombes Himawan Bayu Aji mengatakan bahwa kasus ujaran kebecian (hate speech) tahun 2016 menempati urutan pertama terbanyak diadukan setelah kasus penipuan online (N. K. Novanita, 2017). Permasalahan utama dari semakin banyaknya berita yang kurang lengkap dan tidak dapat disaring oleh penerima berita, maka pada gilirannya akan memungkinkan adanya penggiringan opini satu pihak atau menimbulkan kepanikan di tengah masyarakat.

Untuk dapat memahami konteks literasi informasi dalam konteks pendidikan masyarakat, maka diperlukan adanya pemahaman tentang literasi informasi itu sendiri. Pendapat dari Markauskaite (2006) menyebutkan bahwa istilah literasi informasi cukup bervariasi antara lain sebagai ICT Literacy, digital literacy, ICT Fluency, computer literacy, ICT Skills, technological literacy, media literacy, information literacy, e-literacy, generic skills, $21^{\text {st }}$ century skills, multiliteracies, new literacy, masyarakat informasi, masyarakat virtual, masyarakat maya, global village, global information society, digital divide (kesenjangan digital) dan berbagai istilah lainnya. Sedangkan menurut Verzosa (2009) menyebutkan bahwa literasi informasi adalah sebuah keahlian dalam mengakses dan mengevaluasi informasi secara efektif untuk memecahkan masalah dan membuat keputusan. Seseorang yang memiliki keahlian ini tahu bagaimana belajar untuk belajar karena mereka tahu bagaimana mengelola informasi, mengevaluasi, memilah-milah dan menggunakannya sesuai dengan etika yang berlaku.

Perkembangan teknologi informasi yang pesat saat ini, berdampak pada semakin mudahnya masyarakat mengakses berbagai informasi yang dibutuhkan. Namun demikian membutuhkan kemampuan untuk mencari sumber yang bermutu, mengelola data informasi yang ada dan memilah sumber informasi untuk dimanfaatkan dalam peningkatan kualitas kehidupan itu sendiri, termasuk pemberdayaan masyarakat. Karena tidak semua dokumen, data dan informasi yang tersedia secara elektronik maupun cetak dapat digunakan untuk kebutuhan masyarakat. Sehingga identifikasi kebutuhan dasar menjadi salah satu penguat utama dalam proses pengembangan literasi informasi yang ada di tengah masyarakat.

Walaupun literasi informasi seringkali dikaitkan dengan teknologi informasi, namun dalam kenyatannya seringkali berkaitan dengan berbagai sumber informasi yang digunakan untuk menjadi referensi dalam peningkatan kapasitas kehidupan masyarakat. Baik berupa buku cetak, koran, majalah, jurnal cetak, modul dan sumber fisik lainnya, bisa menjadi salah satu sumber informasi yang bisa digunakan oleh masyarakat dalam rangka membangun dan meningkatkan kapasitas kehidupannya. Dalam konteks ini, literasi informasi yang dimaksud adalah kemampuan untuk memanfaatkan sumber daya yang ada untuk pengembangan kapasitas masyarakat yang ada. 


\section{PEMBAHASAN}

Beberapa ahli telah mengemukakan konsep tentang literasi informasi, sebagaimana yang diungkapkan oleh Doyle (Apriyanti, 2010: 11; S.T. Pattah, 2014: 119) menyebutkan bahwa seseorang disebut memiliki keahlian informasi jika orang yang bersangkutan memiliki ciri sebagai berikut :

- Mampu menyadari kebutuhan informasi

- Mampu menyadari informasi yang akurat dan lengkap merupakan dasar dalam membuat keputusan yang benar.

- Mampu mengidentifikasi sumber-sumber potensial informasi

- Mampu membangun strategi pencarian yang tepat

- Mampu mengakses berbagai sumber informasi termasuk teknologi dasar lainnya

- Mampu mengevaluasi informasi yang diperoleh

- Mampu mengelola informasi untuk menggunakannya sesuai kebutuhan

- Mampu mengintegrasikan informasi yang baru dengan pengetahuan lama yang telah dimiliki.

- Mampu menggunakan informasi dengan kritis untuk penyelesaian masalah

Berdasarkan pada konteks literasi informasi tersebut, maka dapat ditekankan bahwa literasi informasi termasuk di dalamnya adalah kemampuan dalam menemukan, mengorganisasikan, mengevaluasi informasi dan menggunakannya secara efektif serta pemahaman infrastruktur teknologi dalam transfer informasi kepada orang lain baik dalam konteks sosial, politik, budaya, ekonomi, hukum dan implikasinya terhadap kehidupannya secara pribadi maupun sosial.

Coral (1998: 25-29) menjelaskan bahwa keahlian yang penting untuk menjawab tantangan dunia profesi di masa yang akan datang adalah information skills, dan menyetarakan istilah tersebut dengan literasi informasi. Dan ia menambahkan bahwa dalam literasi informasi dibutuhkan dua komponen utama, yaitu kemampuan mengelola dan memanfaatkan teknologi informasi (komputer, gawai, internet dan aplikasi lainnya) dan information handling skills (keterampilan untuk mengelola informasi yang didapatkan). Adapun menurutnya yang dimaksud dengan kemampuan teknologi informasi mencakup pada :

- Keahlian dasar seperti menggunakan keyboard, mouse, printer, file/ disk manager

- Software standar seperti menggunakan word processing, worksheet, basis data dan lainlain.

- Aplikasi jaringan seperti penggunaan email, internet dan web browser

Penguasaan literasi informasi menjadi salah satu syarat utama dalam rangka membangun kapasitas kepribadian terutama kompetensi dan prestasi. Hal ini sesuai dengan hasil penelitian yang dilakukan oleh Murti \& Winoto (2018) yang menyebutkan bahwa semakin tinggi penerapan literasi informasi, maka semakin baik prestasi belajar siswa. Dengan demikian penguasaan literasi informasi menjadi salah satu syarat untuk membangun kemampuan yang lebih baik dalam mengelola dan memanfaatkan berbagai informasi untuk memperkuat kapasitas pribadi dan pencapaian prestasi. Kemampuan literasi informasi menciptakan keberaksaraan berbasis keterampilan yang mencakup pada keterampilan mencari, memilahmilah, menggunakan dan menyajikan secara etis (Pattah, 2014).

Pada sisi yang lain, Doherty (1999: 3) menggambarkan informasi sebagai sebuah komoditi pokok untuk survive. Ia menekankan pentingnya pengguna menjadi pemakai informasi yang 
mandiri dan menjadi melek yang pada gilirannya menjadikan mereka sebagai pembelajar sepanjang hayat (longlife learner), untuk itu pengguna perlu memiliki keterampilan informasi (information skills).

Standing Confrence of National and University Libraries (SCONUL, 1999: 1-12; Pattah, 2014) menguraikan tujuh keterampilan literasi informasi di perguruan tinggi yang meliputi :

1. Kemampuan untuk mengenali informasi yang dibutuhkan.

2. Kemampuan untuk mengenali jensi sumber informasi yang tepat, baik tercetak maupun yang tidak tercetak dan menyeleksi sumber yang sesuai untuk menyelesaikan masalah yang sedang ditangani.

3. Kemampuan membangun strategi untuk menemukan informasi secara sistematis dan memahami prinsip pembuatan dan pengembangan database.

4. Kemampuan mencari dan akses informasi, teknik penelusuran yang tepat, menggunakan teknologi informasi dan komunikasi dan menggunakan layanan indeks dan abstrak yang tepat serta sitiran dan database yang sesuai dengan kaidah.

5. Kemampuan membandingkan dan mengevaluasi informasi yang dihasilkan dari sumbersumber yang berbeda.

6. Kemampuan mengorganisasikan, menggunakan dan mengkomunikasikan informasi kepada orang lain secara tepat, termasuk menggunakan sistem rujukan yang benar, memilah informasi untuk pemecahan masalah yang ditangani dan memahami konteks penggunaan hak cipta dan mampu menghindari tindak plagiat.

7. Kemampuan menggabungkan dan membangun informasi yang ada untuk dapat menciptakan pengetahuan yang baru.

Beberapa konsep tersebut dapat dipilih untuk menajdi model literasi informasi yang tepat dan bisa digunakan oleh mahasiswa untuk mengakses informasi yang dibutuhkan dalam meningkatkan pemahaman dan mendukung peningkatan kapasitas kehidupan masyarakat (Pattah, 2014).

Sedangkan jenis literasi menurut Eisenberg, Lowe \& Spitzer (2004: 7) adalah sebagai berikut

1. Literasi gambar (visual literacy) yaitu suatu kemampuan untuk memahami dan menggunakan gambar termasuk pula kemampuan untuk berfikir, belajar serta mengekspresikan gambar tersebut. Literasi visual dibedakan menjadi 3 yaitu visual learning, visual thinking dan visual communication.

2. Literasi Media (Media Literacy) yaitu suatu kemampuan untuk mengakses, menganalisa dan memproduksi informasi untuk hasil yang spesifik.

3. Literasi komputer (computer literacy) yaitu suatu kemampuan untuk menciptakan dan memanipulasi dokumen dan data menggunakan perangkat lunak pengolah kata, pangkalan data dan sebagainya.

4. Literasi digital (digital literacy) yaitu suatu keahlian yang berkaitan dengan penguasaan sumber dan perangkat digital. Mereka yang mampu mengejar dan menguasi perangkatperangkat digital.

5. Literasi jaringan (network literacy) yaitu suatu kemampuan untuk dapat mengakses, menempatkan dan menggunakan informasi dalam dunia berjejaring misalnya internet, pengguna harus menguasai keahlian ini.

Kemampuan pengelolaan informasi menjadi salah satu pendorong dalam efektivitas pembelajaran juga, karena warga belajar didorong untuk bisa memilah dan menyesuaikan 
program pembelajaran yang dibutuhkan dan disesuaikan dengan permasalahan belajar yang ada, sehingga warga belajar akan lebih memahami makna proses pembelajaran itu sendiri (Muhajang \& Pangestika, 2018). Penggunaan metode pembelajaran yang tepat akan membangun kebermaknaan dan internalisasi nilai hasil pembelajaran yang lebih optimal, dibandingkan hanya sekedar menyampaikan informasi semata (Fitriana \& Mulyono, 2019). Dalam perkembangannya program pendidikan ini lebih menguatkan pada pendekatan pendidikan yang lebih terbuka dan memperluas layanan akses pendidikan, sehingga pendidikan masyarakat akan dibangun dan dikembangan selaras dengan konteks pembangunan masyarakat itu sendiri (Ardiwinata \& Mulyono, 2018).

\section{KESIMPULAN}

Literasi informasi menjadi salah satu daya dukung dalam mengembangkan kesempatan pembelajaran yang jauh lebih baik dibandingkan dengan sistem yang berlangsung secara konvensional. Perkembangan kehidupan yang semakin cepat, didukung dengan capaian teknologi informasi yang semakin luas, memungkinkan setiap sistem pendidikan saling menguatkan satu sama lain, oleh karena itu literasi informasi dan implikasinya terhadap pengembangan program pendidikan masyarakat perlu menjadi salah satu fokus utama saat ini dan di masa yang akan datang, karena sangat dimungkinkan, keterlambatan penguatan pada literasi informasi akan menghambat kualitas pendidikan masyarakat itu sendiri, karena para pengguna menilai adanya ketidaksesuaian antara tantangan dan jawaban yang diberikan oleh pendidikan masyarakat.

\section{DAFTAR PUSTAKA}

Ardiwinata, J. S., \& Mulyono, D. (2018). Community Education in The Development of The Community. EMPOWERMENT: Jurnal Ilmiah Program Studi Pendidikan Luar Sekolah 7 (1), 25-35.

Coral, S. (1998). Key Skills for Student in HIgher Education. . Sconul Newsletter, 15, 22-29.

Eisenberg, Lowe, \& Spitzer. (2004). Information Literacy: Essentials Skills for the Information Age, Edisi ke-2. Westport: Libraries Unlimited.

Fitriana, W., \& Mulyono, D. (2019). Implication of Internship III Programs on Social Competency of IKIP Siliwangi Penmas Students. P2M STKIP Siliwangi 6 (1), 14-20.

Markauskaite, L. (2006). Towards an integrated analytical framework of information and communications technology literacy: from intended to implemented and achieved dimensions. Information Research, 11(3) , 252-265.

Muhajang, T., \& Pangestika, M. D. (2018). Pengaruh Literasi Informasi terhadap Efektivitas Belajar Siswa. Pedagonal: Jurnal Ilmiah Pendidikan, 2(2), 15-22.

Murti, D. P., \& Winoto, Y. (2018). Hubungan Antara Kemampuan Literasi INformasi dengan Prestasi Belajar Siswa SMAN 1 Cibinong, Kabupaten Bogor. Bibliotika: Jurnal Kajian Perpustakaan dan Informasi, 2(1), 1-5. 
Novanita, N. K. (2017, March 26). Kompas.Com. Retrieved from Kompas.Com: https://www.kompas.com/read/2017/03/26/0845611/2016.konten.berisi.ujaran.kebenc ian.paling.banyak.diadukan.ke.polisi

Palupi, R. (2019). Penyalahgunaan Media Sosial Sebagai Alat Propaganda. Jurnal Komunikasi, 10(1), 69-76.

Pattah, S. H. (2014). Literasi INformasi; Peningkatan Kompetensi Informasi dalam Proses Pembelajaran. Jurnal Ilmu Perpustakaan dan Kearsipan Khizanah Al Hikmah, 2(2), 117-128.

Verzosa, F. A. (2007, March 5). slideshare.net. Retrieved from Slideshare.net: https://www.slideshare.net/verzosaf/user-education-and-information-literacyinnovative-strategies-and-practices 